Original Research Paper

\title{
Pelatihan Pembuatan Media Video dan Audio Visual Bagi Guru SD Negeri Gugus V Kecamatan Batukliang Utara Lombok Tengah
}

\author{
Sudirman $^{1}$, Abdul Kadir Jaelani ${ }^{1 *}$, I Ketut Widiada1, Muhammad Tahir', Radiusman ${ }^{1}$ \\ ${ }^{\text {I} P r o g r a m ~ S t u d i ~ P e n d i d i k a n ~ G u r u ~ S e k o l a h ~ D a s a r, ~ F a k u l t a s ~ K e g u r u a n ~ d a n ~ I l m u ~ P e n d i d i k a n, ~ U n i v e r s i t a s ~ M a t a r a m, ~ M a t a r a m, ~}$ \\ Indonesia.
}

https://doi.org/10.29303/jpmpi.v3i2.1112

Sitasi: Sudirman., Jaelani, A. K., Widiada. I. K., Tahir, M \& Radiusman. (2021). Pelatihan Pembuatan Media Video dan Audio Visual Bagi Guru SD Negeri Gugus V Kecamatan Batukliang Utara Lombok Tengah. Jurnal Pengabdian Magister Pendidikan IPA 4(4)

\author{
Article history \\ Received: 02 Oktober 2021 \\ Revised: 20 Oktober 2021 \\ Accepted: 07 November 2021 \\ *Corresponding Author: Abdul \\ Kadir Jaelani, Program Studi \\ Pendidikan Guru Sekolah \\ Dasar, Fakultas Keguruan dan \\ Ilmu Pendidikan, Universitas \\ Mataram, Mataram, Indonesia; \\ Email: aqj_fkip@unram.ac.id
}

Abstract: Banyak sekali peluang berbagai media pembelajaran bagi para guru. Akan tetapi, sangat disayangkan peluang-peluang belum banyak dimanfaatkan oleh guru termasuk media video pembelajaran. Keluhan tidak bisa membuat masih saja menjadi hambatan bagi guru untuk menangkap peluang-peluang tersebut, sehingga pengembangan diri dan karirnya berjalan tidak seperti yang diharapkan. Munculnya keluhan tidak bisa membuat video pembelajaran di kalangan guru tentu saja bukan tanpa sebab. Secara umum ada beberapa kendala yang bisa ditemukan sehingga membuat tingkat partisipasi dalam membuat media pembelajran dikalangan guru ini rendah. Di antaranya rendahnya minat membaca dan menulis, keterbatasan bahan bacaan yang bisa menjadi bahan tulisan, tidak adanya rasa percaya diri, ketidakpahaman guru atas bekal-bekal keilmuan untuk bisa terampil menulis, rendahnya motivasi untuk menulis, minimnya sarana untuk menuangkan ide dan gagasan dalam bentuk jurnal ilmiah.Target yang ingin dicapai dalam pelatihan ini adalah guru SD di Gugus V Kecamatan Batukliang Utara dapat memiliki pemahaman yang baik tentang media pembelajaran khususnya media Video, sebagai media dalam menelurkan ide-ide kreatif, terampil dalam menentukan tema menarik, menguasai langkah membuat video pembelajaran. Metode pelaksanaan dilakukan dengan menjelaskan konsep media pembelajaran, media visual dan media audio visual, mengembangkan media yang menarik khususnya tentang pendidikan, mendemonstrasikan dan menampilkan media audio visual pembelajaran serta memberikan pendampingan kepada peserta. Selanjutnya setelah peserta menyelesaikan membuat media, guru kemudia sosialisasikan kepada peserta didik untuk dapat digunakan. Hasil kegiatan pelatihan ini menunjukkan bahwa para peserta (guru-guru dari Kecamatan Batukliang Utara Kabupaten Lombok Tengah) memberikan sambutan positif terhadap materi yang diberikan. Hal ini terlihat dari antusiasme dan partisipasi aktif mereka terhadap materi dan tugas-tugas yang diberikan selama kegiatan berlangsung. Hal tersebut Nampak dari konsistensi peserta dalam mengikuti seluruh rangkaian kegiatan hingga akhir. Bahkan, semua peserta mengharapkan agar dilakukan kegiatan serupa secara berkelanjutan. Semua guru dari Kecamatan Batukliang Utara yang menjadi peserta berhasil membuat satu contoh media audio visual untuk digunakan dalam pembelajaran yang disesuaikan dengan materi dan kurikulum yang sedang berjalan saat ini. Namun demikian, masih ada peserta yang belum selesai sepenuhnya dalam pembuatan media audio visual dikarenakan keterbatasan waktu dan kendala yang dihadapai saat pelaksanaan PPM, dan factor lain adalah kemampuan peserta berbeda beda dalam mengoperasikan computer dan internet dan aplikasi Camtasia Studio 7. Hal ini menunjukkan bahwa masih perlu memberikan penyuluhan secara lebih intensif kepada guru-guru dalam mengembangkan perangkat pembelajran khususnya perangkat pembelajaran yang mengarah kepada penggunaan Media Audio Visual.

Keywords: Media Audio Visual; Perangkat; Kegiatan pembelajaran. 


\section{Pendahuluan}

Guru menggunakan berbagai jenis model pembelajaran, metode serta alat peraga untuk mempermudah penyampaian ilmu pengetahuan kepada siswa. Alat bantu yang digunakan oleh guru dalam mengajar menyebabkan adanya perubahan motivasi, kondisi belajar dan lingkungan belajar (Hamalik, 1990). Secara umum, alat bantu yang digunakan oleh guru ini disebut dengan media pembelajaran. Media pembelajaran juga dapat diartikan sebagai segala sesuatu yang yang dapat menyalurkan informasi dari sumber informasi kepada penerima informasi (Falahudin, 2014).

Media pembelajaran memiliki banyak manfaat dalam kegiatan pembelajaran, antara lain: sebagai sarana yang membantu dalam mewujudkan kegiatan pembelajaran yang efektif, mempercepat penyampaian informasi dalam prose belajar, meningkatkan kualitas pembelajaran serta mempermudah proses berpikir siswa dari sesuatu yang abstrak menjadi keadaan yang nyata. (Nurseto, 2012).

Media pembelajaran berkembang sangat cepat mengikuti perkembangan zaman. Penggunaan media untuk pengetahuan, pembelajaran dan pedagogi telah bergeser dari masalah penggunaan menuju desain yang lebih efektif (Selwyn \& Oliver, 2011). Perkembangan media dirasa semakin berkembang lebih cepat karena adanya pandemi covid-19. Keadaan pandemi covid-19 menyebabkan perubahan besar di berbagai bidang, khususnya dalam bidang pendididikan. Keadaan pandemi covid-19 menyebabkan kegiatan pembelajaran beralih dari kegiatan pembelajaran tatap muka (luring) menjadi pembelajaran online (daring).

Perubahan sistem pembelajaran ini menyebabkan setiap pendidik dan pendidik harus beradaptasi dengan keadaan yang baru. Pendidik dan peserta didik harus mampu beradaptasi terhadap segala keadaan yang tidak nyaman yaitu pembelajaran daring. Pendidik harus mampu melakukan inovasi dalam melakukan kegiatan pembelajar, mulai dari penyiapan soal secara online, pembuatan media pembelajaran secara online, serta situasi lain yang tidak mendukung kegiatan pembelajaran.

Salah satu inovasi yang dapat dilakukkan adalah pembuatan media pembelajaran. Media pembelajaran bukan hanya berfungsi sebagai alat bantu saja melainkan sudah dipandang sebagai bagian yang terintegrasi dalam dunia pendidikan (Selamat, 2020). Media pembelajaran dapat dibagi media pembelajaran audio, media pembelajaran audio visual diam dan media pembelajaran audio visual bergerak (Nurseto, 2012). Media pembelajaran audio adalah sebuah media pembelajaran yang komponen utamanya adalah suara, media pembelajaran audio visual diam adalah media pembelajaran yang faktor utamanya adalah suara, gambar atau grafik, garis dan simbol gerak (motion), sedangkan media audio visual gerak adalah sebuah media pembelajaran yang komponen utamanya adalah suara, gambar atau grafik, garis, simbol verbal atau tulisan dan gerak (motion) (Hamid et al., 2020).

Media pembelajaran visual merupakan suatu media pembelajaran yang berhubungan dengan indera pengelihatan. Media pembelajaran visual ini merupakan salah satu media yang memegang peranan penting kepada anak yang memiliki gaya belajar visual, dimana indera pengelihatan menjadi faktor utama yang membantu peserta didik dalam memahami pelajaran. Contoh dari media pembelajaran visual adalah video, bagan, skema, jadwal, grafik dan gambar (Mahnun, 2012). Selanjutnya untuk media pembelajaran audio visual merupakan suatu media pembelajaran yang memiliki unsur suara dan unsur gambar yang dapat dilihat dan didengarkan suaranya (Virgiana \& Wasitohadi, 2016). Media pembelajaran audiovisual ini sangat cocok dalam membantu peserta didik yang memiliki gaya belajar audio dan visual. Contoh Dari media pembelajaran audio-visual adalah rekaman video, film dan slide suara (Sanjaya, 2007).

Media pembelajaran merupakan salah satu bagian yang sangat mendukung dalam kegiatan pembelajar. Media pembelajaran dalam dijadikan alat pengganti guru dalam menyajikan materi pembelajaran di dalam kelas. Segala kesulitan yang dialami oleh siswa dalam memahami pelajaran dapat dibantu dalam pengguanaan media(Ainina, 2014). Penggunaan media pembelajaran masih menjadi suatu kendala yang dialami oleh setiap guru. Guru lebih memilih untuk mempertahankan sikap statis dan masih menggunakan cara-cara konvensional dalam melakukan kegiatan pembelajaran di dalam kelas (Mahnun, 2012). Hal ini akan menyebabkan siswa merasa kebosanan dalam melaksanakan kegiatan pembelajaran. 
Berdasarkan hasil identifikasi terhadap guruguru sekolah dasar gugus V Aiq Bukak, Kecamatan Batukliang, Lombok tengah maka ditemukan beberapa permasalahan terhadap pembuatan maupun penggunaan media pembelajaran, antara lain:

1. Kurangnya pemahaman manfaat penggunaan media pembelajaran visual dan audio visual dalam kegiatan pembelajaran.

2. Kurangnya penggunaan media pembelajaran visual dan audio visual dalam kegiatan pembelajaran.

3. Kurangnya kreativitas pembuatan media pembelajaran yang sesuai dengan pelajaran yang diajarkan dalam pembelajaran.

Berdasarkan permasalahan yang dialami oleh guru-guru gugus V Aiq Bukak, Kecamatan Batukliang, maka tim pengabdi berencana melakukan sosialisasi berupa pelatihan pembuatan media pembelajaran visual dan audio-visual. Kegiatan pengabdian ini bertujuan agar guru-guru gugus V Aiq Bukak, Kecamatan Batukliang mampu membuat media pembelajaran tersebut sehingga dapat membantu peserta didik dalam memahami kegiatan pembelajaran dan suasana belajar di dalam kelas tidak membosankan.

\section{Metode}

Metode yang digunakan dalam kegiatan pengabdian kepada masyarakat ini adalah metode koordinasi, observasi, komunikasi, sosialisasi dan pelatihan. Pelaksanaan kegiatan pelatihan pembuatan media pembelajaran visual dan audiovisual di gugus $\mathrm{V}$ Kecamatan Batukliang Utara ini adalah sebagai berikut:

Kegiatan koordinasi dalam pelakasanaan kegiatan pengabdian kepada masyarakat di SD Negeri gugus V Aiq Bukak dilakukan sebelum kegiatan pengabdian berlangsung. Kegiatan koordinasi ini dilakukan dengan cara melakukan pembagian tugas antara tim pengabddi serta mendiskusikan kegiatan yang akan dilakukan selama kegiatan pengabdian berlangsung.

Kegiatan observasi dilakukan dengan cara mengunjungi SD Negeri gugus V Aiq Bukak. Tujuan dari kegiatan observasi ini adalah untuk mengetahui permasalahan terhadap tersedia atau tidaknya media pembelajaran visual dan audiovisual. Kegiatan observasi ini juga bertujuan untuk menjalin kerjasama dan persetuan terhadap pelaksanaan kegiatan pengabdian masyarakati ini.

Kegiatan komunikasi dilakukan kepada sesama anggota tim pengabdi dalam kegiatan penyusunan proposal yang berkaitan mengenai materi, alat dan bahan yang akan digunakan selama kegiatan pengabdian berlangsung, serta hal-hal yang akan dibutuhkan selama kegiatan pengabdian berlangsung

Kegiatan komunikasi juga dilakukan antara tim pengabdi dengan mitra. Kegiatan komunikasi ini bertujuan untuk menjalin komunikasi dengan mitra tentang waktu pelaksanaan, kegiatan pelaksanaan serta sarana-prasarana yang dibutuhkan selama kegiatan pengabdian berlangsung. Setelah kegiatan persiapan dilakukan, maka tim pengabdi melakukan kegiatan yang diawali dengan kegiatan sosialisasi. Sosialisasi dilakukan dengan memberikan penjelasan dengan materi pengertian media pembelajaran visual dan audio visual, pembelajaran dengan menggunakan media pembelajaran serta pembuatan media pembelajaran.

Pada tahapan pelatihan maka tim pengabdi melakukan pelatihan pembuatan media pembelajaran visual dan audio visual. Adapun kegiatan yang akan dilakukan oleh tim pengabdi adalah sebagai berikut:

1. Penyampaian materi mengenai media pembelajaran

2. Penyampaian materi mengenai media visual

3. Penyampaian materi mengenai media audio visual

4. Pelatihan pembuatan media pembelajaran

\section{Hasil dan Pembahasan}

Kegiatan pengabdian pada masyarakat periode tahun 2021 ini dilaksanakan selama kurun waktu 6 bulan di wilayah kecamatan Batukliang Utara. Sasaran dari kegiatan tersebut adalah guru guru yang tergabung di gugus $\mathrm{V}$ Kecamatan Batukliang Utara. Adapun lokasi pelaksanaan dipusatkan di SD Negeri Aiq Bukaq dengan jumlah peserta 30 orang diambil secara random dari semua sekolah yang ada di Gugus V Batukliang Utara. Adapun tahap tahap kegiatan yang dilaksanakan dapat dijabarkan sebagai berikut:

Tahap Persiapan, Pada tahapan ini, seluruh anggota Tim PPM melakukan persiapan dengan melakukan koordinasi dan penyamaan persepsi 
melalui beberapa kali pertemuan tentang mekanisme maupun teknis pelaksanaan PPM. Tanggal 12 juli 2021, Pukul 14.00 - 18.00, bertempat di ruang Kajian dan Pengembangan KeSD-an FKIP Unram Kampus-2, dihadiri oleh seluruh anggota Tim-PPM membahas dan menghasilkan materi pelatihan sesuai topic yang diusulkan. Selanjutnya ketua tim berkoordinasi dengan ketua gugus V Kecamatan Batuklian Utara guna menyampaikan informasi terkait materi maupun rencana waktu pelaksanaan kegiatan pengabdian. Berikutnya pada tanggal 25 Juli 2021, Pukul 14.00 - 16.00, di tempat yang sama, dihadiri oleh seluruh anggota Tim-PPM melakukan pembahasan dan penyempurnaan materi pelatihan. Hasil final materi pelatihan disepakati dan dihasilkan pula slide power-point sebagai bekal penyajian dalam pelatihan.

Tahap Pelaksanaan, Kegiatan pelatihan ini dilaksanakan selama satu hari penuh. Pelatihan dilaksanakan secara tatap muka di SD Negeri Aiq Bukaq yang diikuti oleh 30 peserta dan 5 orang tim pelatih. Kegiatan pelatihan diawali oleh kegiatan seremonial pembukaan yang dibuka oleh Ketua Gugus V Batukliang Utara, dimaksudkan sebagai acara pembukaan sekaligus ajang penyajian sejumlah informasi tentang pentingnya profesionalisme guru dan sosialisasi kebijakan kebijakan pemerintah. Di samping itu juga sebagai bentuk ramah tamah antara pihak Sekolah dengan Tim PPM bertujuan untuk menjalin keakraban dan kekeluargaan dalam setiap kegiatan, sehingga diharapkan kegiatan kegiatan serupa dapat dilaksanakan secara berkesinambungan. selanjutnya ketua Tim PPM juga menyampaikan sambutan dan apresiasi kepada pihak sekolah dan seluruh peserta perwakilan guru, serta menyampaikan informasi up to date terkait perkembangan pendidikan dan pembelajaran. Sebelum kegiatan dilanjutkan ke tahap penyampaian materi, Tim PPM terlebih dahulu melakukan pretest untuk menggali kemampuan awal peserta pelatihan terkait pembuatan dan penggunaan media audio visual dalam pembelajaran. Kegiatan Pre-test dimaksud agar mendapatkan informasi awal tentang taraf kemampuan peserta sebelum pelatihan dilaksanakan. Pelatihan ini menerapkan metode drill yang dalam operasionalnya tetap memperhatian tahapan-tahapan drill yaitu tahap integratif, tahap fiksasi dan tahap otonom.
Sesi 1, dilaksanakan pembahasan (Tahap Integratif) tentang beberapa materi yang telah di persiapkan, yaitu Konsep Media Pembelajaran, Pembuatan dan Penggunaan Media Visual, Pebuatan dan Penggunaan Media Audio Visual. Penyampaian masing masing materi diberikan waktu masing masing 50 menit. Materi pertama salah satu Tim PPM menyampaikan materi tentang Konsep Media Pembelajaran secara umum. Hal ini perlu dilakukan agar peserta memperoleh paradigma yang benar tentang media pembelajaran, bahwa media bukan sekedar alat atau fasilitas belajar saja, namun lebih kepada sesuatu yang dapat membantu siswa memahami materi pelajaran. Materi kedua tentang pembuatan media Visual, yaitu salah satu jenis media yang cukup efektif dalam menggambarkan materi pelajaran. Perkembangan media dirasa semakin berkembang lebih cepat karena adanya pandemi covid-19. Keadaan pandemi covid-19 menyebabkan perubahan besar di berbagai bidang, khususnya dalam bidang pendididikan. Materi ketiga adalah pembuatan media audio visual, Media pembelajaran audio adalah sebuah media pembelajaran yang komponen utamanya adalah suara, media pembelajaran audio visual diam adalah media pembelajaran yang faktor utamanya adalah suara, gambar atau grafik, garis dan simbol gerak (motion), sedangkan media audio visual gerak adalah sebuah media pembelajaran yang komponen utamanya adalah suara, gambar atau grafik, garis, simbol verbal atau tulisan dan gerak (motion) (Hamid et al., 2020).

Sesi-2, latihan praktek pembuatan media audio visual selama $3 \times 50$ menit. Peserta dilatih untuk menggunakan program aplikasi computer yaitu Camtasia Studio 7. Pertama tama yang pelatih lakukan adalah memperkenalkan aplikasi tersebut dan cara penggunaannya.Selanjutnya masing masing peserta menginstall aplikasi dan secara serentak dan dengan simulasi pelatih mempertunjukkan cara menggunakan aplikasi tersebut setahap demi setahap. Pada awal kegiatan peserta cukup kesulitan beradaptasi dengan program tersebut, namun saat tahap pengulangan sudah mulai lebih lancer dalam menjalankan program tersebut. Maka pada tahap ini terlihat sebagian besar peserta sekitar $83,33 \%$ peserta dapat menggunakan aplikasi secara benar dan lancer berdasarkan contoh yang ditunjukkan. 


\begin{abstract}
Sesi-3, pelatihan dilanjutkan dengan pembahasan (Tahap Integratif), yaitu mendiskusikan kembali hasil simulasi kelompok yang dilakukan oleh pelatih. Dilanjutkan dengan memberikan kesempatan tanya jawab pada peserta. Tampaknya peserta pelatihan lebih tertarik untuk langsung melakukan latihan. Kegiatan ini berlangsung sampai pukul 15.30 wita. Temuan di lapangan dari hasil diskusi dan Tanya jawab tersebut bahwa sebagian besar $90 \%$ peserta telah familiar menggunakan perangkat laptop dan internet, dan yang sudah lancar dalam mengoperasikan Camtasia Studio 7 sekitar $80 \%$ dari seluruh peserta.
\end{abstract}

Sesi-4. Tim pelatih kembali di sebar untuk memberikan soal posttest untuk mengukur kemampuan akhir dan mendiagnosis serta memberikan bimbingan langsung terhadap temuantemuan yang dianggap kurang memadai khususnya bagi peserta yang masih mengalami kesulitan dalam mengoperasikan aplikasi yang digunakan. Tim pelatih kembali mencatat temuan-temuannya agar dapat disampaikan di depan kelas.

Secara umum, hasil pelatihan menunjukkan bahwa para peserta (guru-guru dari Kecamatan Batukliang Utara Kabupaten Lombok Tengah) memberikan sambutan positif terhadap materi yang diberikan. Hal ini terlihat dari antusiasme dan partisipasi aktif mereka terhadap materi dan tugastugas yang diberikan selama kegiatan berlangsung. Hal tersebut Nampak dari konsistensi peserta dalam mengikuti seluruh rangkaian kegiatan hingga akhir. Bahkan, semua peserta mengharapkan agar dilakukan kegiatan serupa secara berkelanjutan. Semua guru dari Kecamatan Batukliang Utara yang menjadi peserta berhasil membuat satu contoh media audio visual untuk digunakan dalam pembelajaran yang disesuaikan dengan materi dan kurikulum yang sedang berjalan saat ini. Namun demikian, masih ada peserta yang belum selesai sepenuhnya dalam pembuatan media audio visual dikarenakan keterbatasan waktu dan kendala yang dihadapai saat pelaksanaan PPM, dan factor lain adalah kemampuan peserta berbeda beda dalam mengoperasikan computer dan internet dan aplikasi Camtasia Studio 7. Hal ini menunjukkan bahwa masih perlu memberikan penyuluhan secara lebih intensif kepada guru-guru dalam mengembangkan perangkat pembelajran khususnya perangkat pembelajaran yang mengarah kepada penggunaan Media Audio Visual.

\section{Kesimpulan}

Berdasarkan pelaksanaan kegiatan Pengabdian Pada Masyarkat maka dapat ditarik kesimpulan sebagai berikut:

1. Kegiatan pelatihan pembuatan video audio visual dapat terlaksana sesuai dengan tempat dan waktu dan peserta yang telah direncanakan. Kegiatan ini diikuti oleh guru-guru SD Negeri di kecamatan Batukliang Utara Kabupaten Lombok Tengah berjalan lancar sesuai harapan, serta mengahadirkan kepala sekolah dan Ketua Gugus V Kecamatan Batukliang Utara.

2. Kemampuan peserta menggunakan laptop dan internet dalam pembelajaran sangat baik mencapai $90 \%$ lancar menggunakan perangkat, dan sebagian besar peserta $80 \%$ lancar mengoperasikan aplikasi untuk membuat audio visual yaitu Camtasia Studio 7.

3. Kendala yang terjadi saat kegiatan berlangsung antara lain: laptop gangguan, gangguan sinyal, baterai laptop dan carger, ada peserta yang bingung dalam install program/aplikasi, maupun mengoperasikan program pembuatan media audio visual.

4. Tingkat keberhasilan kegiatan mencapai hasil pretest 11,350 dan posttest sebesar 15,325 dengan nilai gain ternormalisasi sebesar 0,412 yang menunjukkan tingkat keberhasilan berada pada kategori sedang. Hal ini sesuai dengan antusiasme dan respon peserta pada saat mengikuti kegiatan pelatihan dan menyelesaikan tugas membuat video audio visual dalam pembelajaran.

\section{Ucapan Terima Kasih}

Ucapan terimakasih kami sampaikan kepada Bapak Rektor Universitas Mataram dan Bapak Dekan Fakultas Keguruan dan Ilmu Pendidikan yang telah memberikan dukungan dana PNBP pelaksanaan Pengabdian Pada Masyarakat dari dana DIPA BLU Universitas Mataram Tahuna Anggaran 2021 dengan nomor kontrak. Demikian juga kepada Bapak Ketua Gugus V Kecamatan Batukliang Utara Kabupaten Lombok Tengah, Kepala SD Negeri Aiq Bukak, yang telah merespon dan mendukung keterlaksanaan kegiatan PPM ini dengan mengirimkan para peserta, terlebih khusus bapak Kepala SD Negeri Aiq Bukak telah 
menyiapkan ruang kegiatan yang standar protokol keseshatan sehingga kegiatan PPM dilaksanakan dengan lancar.

\section{Daftar Pustaka}

Bandule, Yanderson. 2013. Pengembangan Budaya Sekolah Berbasis Pendidikan Karakter. Artikel. PPs Universitas Negeri Gorontalo.

Berman, M. 2001. Developing SQ (Spiritual Intelligence) Through ELT. Available onhttp://www.spiritualintelligence.com

Buhang, Widya. 2013. Pengelolaan Kelas Berbasis Pendidikan Karakter di SMPN 1 Kaidipang Sulawesi Utara. Artikel. PPs Universitas Negeri Gorontalo.

Golemen, D. Kecerdasan Emosional untuk Mencapai Puncak Prestasi. Terjemahan oleh Alex Tri Kartjono Widodo, 1999. Jakarta: Gramedia Pustaka Utama.

Hamruni. 2008. Mengembangkan Dimensi Spiritual-Etik dalam Wawasan Ilmu Pendidikan. Yogyakarta: Jurnal Kependidikan Islam. Vol 3, no 1 JanuariJuni 2008

Masaong, A.K. 2011. Kepemimpinan Berbasis Multiple Intelligence; Memperteguh Sinergy Kecerdasan Intelektual, Emosional, dan Spiritual untuk Meraih Prestasi Gemilang. Bandung: Alfabetha.

Masaong, A.K. 2014. Hubungan Kecerdasan dan Perilaku Kepemimpinan Kepala Sekolah dengan Penguatan Karaskter Siswa di SMP Se Kota Gorontalo. Artikel. 